\title{
Orhan Kemal, Kemal Tahir ve Yaşar Kemal'in romanlarında mizojinik söylemlerin analizi
}

Aziz ŞEKER1

APA: Şeker, A. (2019). Orhan Kemal, Kemal Tahir ve Yaşar Kemal'in romanlarında mizojinik söylemlerin analizi. RumeliDE Dil ve Edebiyat Araştırmalar Dergisi, (15), 136-146. DOI: 10.2900o/rumelide.580486

$\ddot{O} \mathbf{z}$

Şiddet toplumsal bir olgudur. Şiddetin insan hakları ve halk sağlığı boyutu üzerine önemli araştırmalar yapıldığı bilinmektedir. Şiddetin edebî metinlerdeki yansımasıyla ilgili çalışmalar ise feminist edebiyat eleştirisinin gelişimiyle daha çok ilgi çekmeye başlamıştır. Bu çalışmada edebiyatın biri türü olarak kabul edilen romanlarda geçen şiddetin, kadın karakterler bakımından özellikle sembolik/sözel kısmına eğildik. Örneklemimizi çağdaş Türk edebiyatının tanınan yazarları Orhan Kemal, Kemal Tahir ve Yaşar Kemal'in romanlarıyla sınırlandırdık. Her üç yazarın romanlarında, kadınların fiziksel şiddet dışında, kamusal ve mahrem alanda eril dilin ötekileştirici ve aşağılayıcı sözcükler (mizojinik söylemler) kullanılarak nasıl nitelendirildiğini çözümlerken, en sık kullanılan sözcüklerden yola çlkarak sosyolojik bir değerlendirmede bulunduk. Çalışmanın, romanın kurgulandığı toplumsal yapıda, kadın gerçeğini erkek dilinde hangi söylemlerle özdeş tuttuğunu görmek açısından, yapılacak tartışmalara katkı sağlayacağı düşünülmektedir.

Anahtar kelimeler: Mizojini, toplumsal cinsiyet, roman.

\section{An analysis of misogynist discourses Orhan Kemal, Kemal Tahir and Yaşar Kemal's novels}

\begin{abstract}
Violence is a social phenomenon. Significant research is being carried out on the human rights and public health dimension of violence. Studies on the reflection of violence in literary texts, on the other hand, began to attract more attention with the development of feminist literary criticism. In this study, we focused on especially the symbolic/verbal aspects of violence in terms of female characters in the novels, which are accepted as a literary genre. We limited our sample to the novels of Orhan Kemal, Kemal Tahir and Yasar Kemal, three of the distinguished novelists of Turkish literature. We analyzed in the novels of all three writers the ways in which women are characterized by the use of marginalized and degrading words (misogynist discourses) in public and private space, except physical violence and based on the most frequently used words, we made a sociological assessment. It is thought that the study will contribute to the efforts to find out about what discourses are employed by men for women in the social structure in which the novel is built.
\end{abstract}

Keywords: Misogyny, gender, novel.

Dr. Amasya Üniversitesi, (Amasya, Türkiye), shuaziz@gmail.com, ORCID ID: oooo-ooo1-5634-0221 [Makale kaylt tarihi: 19.03.2019-kabul tarihi: 16.06.2019; DOI: 10.29000/rumelide.580486] 


\section{Giriş}

Şiddet, çağın dünyasında, tanımı en zor yapılabilen ve hayatın her katmanında yaşanan bir olgudur. Kendi hayatlarımızın özgül katmanları, koşulları karşısında tanımlamaktan başlayarak, toplumsal coğrafyanın açıkça politik bir tavır talep eden atmosferindeki karşılığını bulmaya kadar, çağdaş insanı belki de en meşgul eden konuların başında gelmektedir (Türker 1997: 319). Şiddet edebiyatta özellikle roman türünde de önemsenen bir konu olagelmiştir. Romanda şiddet türleri içinde, konumuz açısından erkeğin kadına yönelik uyguladığı şiddetin bir boyutu kabul edilen sözel şiddet üzerinde durduk. Romanda şiddet karakterler arasında sözcükler yolu ile işleniyorsa, bireysel patolojileri göz önünde tutarak toplumsal arka planı çözümlemenin kadının inşa edildiği toplumsal koşulları görmek açısından aydınlatıcı olduğunu söyleyebiliriz. Kuşkusuz bu, dilin toplumsal cinsiyeti içselleştiren doğasını görmek bakımından analiz edilmesi gereken süreçlerden biridir. Çünkü "toplumsal bir olgu olan dil özellikle de sözlü dilin kullanımının belirli durumlarda cinsiyetli olduğu dilbilimciler tarafindan saptanmıştır” (Collin, Kaufer 2016: 162).

Toplumsal cinsiyet açısından kadınlara yönelik olarak kullanılan cinsiyeti aşağılayıcı sembolik içerikli dahi olsa şiddet eksenli kavramlar, toplum içerisinde her toplumsal kesimden erkekler tarafindan rahatlıkla erkek söyleminde kullanıldığı gibi erkek egemen hiyerarşiyi içselleştiren kadınlar tarafından da kendi türleri için kullanılabilmektedir. Amacı toplumsal yapıyı çeşitli yönleriyle vermek olan romanda kadın karakterler oluşturulurken, toplumsal gerçekliklere sıklıkla bağlı kalındığı gözlenmektedir. Başlangıçta söyleyelim ki, kadına yönelik sözel şiddetin boyutları, kadını ayrıştırıcı ve nefrete dayalı (mizojinik) söylemlerin ve ötekileştirici sözcüklerin yaygınlığını yazarların, olanı yansıtan rolleriyle değerlendirmekteyiz. Çünkü toplum içindeki insan ilişkilerinde yer yer kullanılan bu söylemleri roman karakterlerinin tercih etmesi, toplum içerisinde söylemlerin kabullenişleriyle ve kullanım yerleriyle ilişkilendirilmelidir. Ayrıca bu nitelendirmeleri, romancının roman olayları içinde kişilerin kendi aralarında kadınlara karşı kullandıkları sözcükleri vermek adına, toplumsal gerçeğin kadın ve erkek kimliklerine atfettiği değerleri yansıtma girişimi olarak da okumak gerekir. Aksi takdirde sosyolojik anlamda büyük oranda sınırlandırılmış bir bakış açısıyla hareket etmiş olmakla birlikte yalnızca yazara odaklanmış oluruz.

Neredeyse insanla yaşıttır sanat. Bu birliktelik insanlık boyunca sürerken sanat yapıtlarına da insanların yapıp ettikleri yansımıştır (Fischer, 1993: 15). Örneğin günümüzden 3.500 yll önce kadın; önce babanın, sonra kocanın malı sayıldı. Kadın ev işlerinde biraz savsak, savruk davranmışsa; erkek yeniden evlenebiliyor, ilk karısı da evin kölesi oluyordu. Durumun en ağlatısal, en açıkı yanı; kocası ölen kadın evlenirse öldürülüyordu. Daha açık bir söyleyişle, kadının kocasının ölümünden sonra evlenmesi ihanet sayılıyordu. Kadın kölenin bedeni, evin sahibine aitti... Bu gelenekler sanatın kurgusunda çoğu zaman yer almıştır (Ergüven, 1988: 90). Bir tarihsellik içinde ele alındığında çok öteden beri sanatsal yapitların bir kısmında kadınlara karşı bir olumsuzlama görülür. Bahrani’nin değerlendirmesiyle, Mezopotamya'da, kadın edilgenlikle, doğayla ve bedenin kendisiyle özdeşleştirilirken erkek faillik sahibi toplumsal ve etkin bir varlıktır. İmge ve temsil anlamında sanatta cinsellik taşıyan bedeniyle kadın çıplak resmedilir. Akad ve Sümer edebiyatında kadın bedeninin görsel açıdan çekici ve cinsel açıdan alımlı yönü olarak tanımlanan şey, sadece vulva değildir; bunun yanı sıra kadın çıplaklığı daima baştan çıkarıcı, cazibeli ve karşı konulmaz addedilir. Akad ve Sümer edebiyatında cazibe ve baştan çıkarıcılık bir kadında en aranılan niteliklerdir, tıpkı erkekte aranılan şeyin zindelik olması gibi (Bahrani 2018: $108,128,158)$. Bunun yanında yer yer mizojinik bir içerik barındıran, "Yunan edebiyatı kadın cinselliğine ve özellikle de kadın cinsel organlarına karşı korku ve kinle doluydu. Cinsel açıdan faal kadın, zincirlerinden boşanmak için pençe atan yabani bir mengiç, bir kancık köpek, bir merkep, bir 
çakal” şeklinde görülmüştür. Sonuçta yukarıda sözü edilen kültürlerdeki toplumsal cinsiyet ideolojisi, kendi toplumlarına özgü olmakla birlikte genelde eril çıkarların taleplerine tabi olmuşlardır (Golden 1988: Carson 1990 akt; Bahrani 2018: 142, 166). Dünya edebiyatında bazı ünlü romanlar incelendiğinde bile kadının ikincil konumuyla karşılaşmamak olanaksız gibidir. Bu açıdan Stendhal'ın Parma Manastırı romanına kısaca bakalım: Korkak kabul edilmek istemeyen Fabrice'nin bir tutuklunun adını taşıyarak katıldığı savaştan sonra, kendisine saldıran birini öldürmesiyle mâhkum edildiği roman, Clêlia'ya duyduğu aşkın dışında, kadın temsillerini, dönemin toplumsal koşullarını ve toplumsal cinsiyet hiyerarşisini analiz etmek yönüyle de önemli bir içeriği sahiptir. Romanın genelinde rastladığımız; sıradan kadınlarnn kuruntusu, zayıf bir kadına yaraşan kuşkular, yaşl bir kadına yaraşır gülünç işler, en can sıkıcı kadın, aşağılık kadın, kadınlar her zaman kadındır... türündeki tanımlamalar kullanılan cinsiyetçi değerlendirmelerden bir kaçıdır. Parma Manastırı'nda geçen şu satırlar cinsiyetçi praxis yönüyle dikkate değerdir: “...bu sarayda, düşeşler, prensesler, İspanya soylularının eşleri kendiliklerinden otururlar. Öbür kadinlar prensin ya da prensesin kendilerine oturmalarm söylemelerini beklerler. Simıflar arasındaki ayrmı iyice belirtmek için de bu yüce kişiler düşeş olmayan hanımları oturmaya davet etmeden önce kısa bir süre geçmesine her zaman büyük özen gösterirler" (Stendhal 1993: 133).

Türk romanının gelişimine bakıldığında birçok eserde kadının roman karakteri olarak, erkeğin belirlediği bir dünyada yaşam mücadelesi verdiğine tanık oluruz. Bu yönüyle Tanzimat romanında kadın, kamusalda tam anlamıyla yer alamadığı için toplumsal görünürlüğü zayıftır ve mahrem alanda da erkek egemen bir ataerkilliğin kendisine tanıdığı sınırlara hapsolmuştur. Şiddetin çeşitli boyutlarıyla karşı karşıya bırakılabilir. Cumhuriyet dönemiyle değişen roman örgüsünde, kadın ikincil/yan karakter olma özelliğini göreceli bir biçimde sürdürürken, ailesine ve topluma hizmet eden özellikleriyle meşruluk kazanan bir kimliğe sahip olur. Romanın kendisi kadınlar açısından erkek egemen ideolojiyle hesaplaşma mücadelesini yerine getiremediği için kadının konumunu, toplumsal yaşam içindeki gerçekliği ve ondan beklenen rollerin işlevlerini yerine getirme isteği belirlemiştir. Öte yandan zamanla ortaya çıtığı koşullarda bir anlamı olan toplumcu edebiyatın, Türkiye koşullarında tartışılmaya başlandığı 1950 sonrası Türk romanında ise daha farklı toplumsal kesimlere, bunlar arasındaki çatışmalara ve bu değişen sosyal yapının getirdiği toplumsal gerçeklerle biçimlenen kadın/erkek temsillerine rastlarız. Kadın roman karakterleri ataerkil sistemin dayatmalarını yaşarken, insani bakımdan değişen koşullarda bir yaşam mücadelesi verirler. Kötü çalışma koşullarında; fabrikalarda, tarlalarda, marjinal işlerde çalışırken karşılaştıkları güçlükler pek çok romanda işlenmiştir. Örneğin toplumcu kuşağın üç önemli romancısı Orhan Kemal, Kemal Tahir ve Yaşar Kemal, değişen toplumsal yapıyı daha bütünsel ve gerçekçi aktaran roman dünyalarını toplum gerçeklerine dayandırmayı ihmal etmezken, oluşturdukları karakterler yoluyla da bunu vermişlerdir. Kadınların toplumsal yapı içinde yaşam stratejilerini belirlemek noktasında adeta seçme şanslarının ve özgürlüklerinin olmayışı, okuyucu için vicdani hesaplaşma ve bir dram kaynağı olabilmektedir. İşte bu esnada yazarlar kadınların yaşamlarını yansıtırken, erkek egemen toplumda kadın aleyhinde üretilen mizojinik söylemelere işlev yüklemeyi de ihmal etmezler. Yine toplumsal gerçek kadına hangi değerleri yüklüyorsa genelde bu yoldan gitmeyi tercih etmişlerdir. Çünkü okuyucunun gerçekleri bilmesini önemsemişlerdir.

Diyebiliriz ki edebiyat toplumu görmek adına araştırmacılara, "kapıyı aralar, pencere açar, bir ufka götürür onu. Edebiyatta insanın sözü, insan eyleminin yoğunluğu ve karmaşıklğı, insan hadisesinin bütün detayları ve ayrıntıları vardır" (Alver 2018: 17). Bu detaylar içinde kadına ağırlıklı olarak eğilip, kadın gerçekliğinin toplum içindeki temsillerini ve ataerkilliğin biçimlendirdiği bakış açısını ele alıp kritik ettiğimizde karşımıza pek de olumlu bir tablo çıkmaz. Biz de bu metin çalışmasında; her üç yazarın kitaplarında kadınların sosyal-ekonomik-kültürel konumunu göstermekten çok, erkek ve kadın 
dünyasında insan ilişkilerinde kadına yönelik hangi mizojinik söylemlerin yaygın olarak kullanıldıklarını sergilemeye çalıştık.

\section{Orhan Kemal'in romanlarında kullanılan mizojinik söylemler}

Orhan Kemal'in romanları toplumsal cinsiyet sosyolojisi açısından çözümlenirken, bu gerçekçi romancının genel hatlarıyla toplum içinde çeşitli alanlarda kadın temsillerine yer verdiğini söylemek mümkündür. Kadınların toplum içindeki temsilleri işlenirken, erkekler tarafından kurulan ve yeniden üretilen dilde, kadınlık durumlarını aşağılayan mizojinik söylemlerin sıkça kullanıldığını ise birçok örnekte görmekteyiz. Bu kısımda söz konusu söylemler saptanırken, toplum içinde kurulu dilde kadınlarla ilgili olumsuzlama içerdikleri kullanımlarıyla ortaya çıkarılmışlardır. Orhan Kemal’in romanlarında bunu örnekleyecek kelime ve cümleleri şu şekilde verebiliriz:

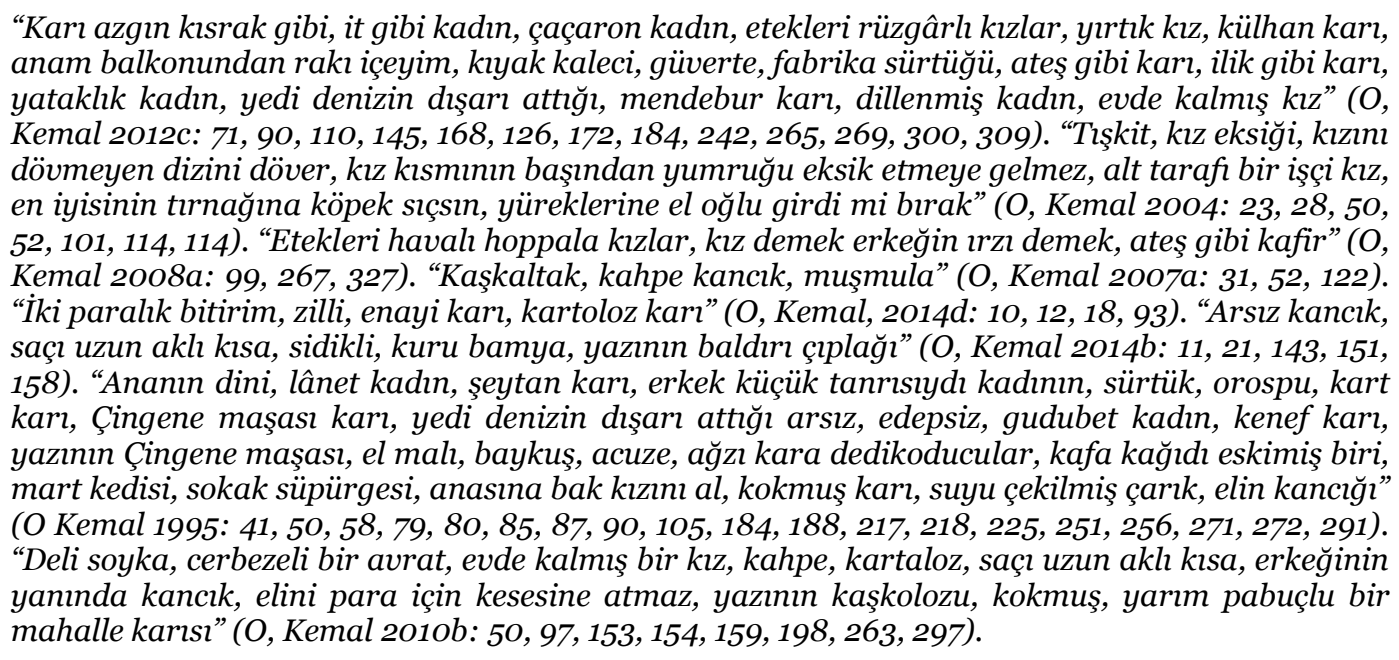

"Erkek yüzlü kız, maymun, sürtük, fingirdek yellozlar, kenar mahallenin hastahkl kızlar, kancık köpek, kuyruğunu sallamazsa erkek köpek ardından gitmez, ateş gibi kız, beş kuruşluk hizmetçi, afto, bir kadın, bir kzz çalş̧t mi, elini yıka" (O, Kemal 2015a: 1, 52, 54, 105, 127, 169, 188, 240, 269, 286). "Kocakarı, beş paralık sürtük, yedi denizin dışarı atth̆ sürtük, sevici karl, inek karı, azgın karl, kapatması, metresi, kıyak bir karı, kirli bir paçavra, bıldırcın gibi karılar, o biçim kadınlar, kocakarı, çaçaya benziyor, kuru bamya teyze" (O, Kemal 2014a: 5, 32, 34, 36, 37, 111, 155, 170, 171, 179, 186, 189). “Edepsiz karl, pis cenabet, karakus,, beslemede kızlk mı korlar, kokoz, orospu, kanclk köpek kuyruk salladıysa erkek köpeğin suçu neydi, geçkin hanım, küçük bir kâtip karısı, sürtük, kafir kız, soyka, kızı kendi keyfine burakırsan ya davulcuya varır, ya zurnacıya, kenarm dilberi, sarışı bomba, ciğeri iki para etmez bir sürtük, onun yeri bar, saz, belki de kerhane, isterik kadın, kart karl, ilik gibi kadın" (O, Kemal 2015d: 22, 28, 33, 35, 38, 41, 65, 67, 69, 76, 8o, 82, 86, 103, 104, 116).

"Yosma, kahpe kzz, bir kzz kendi keyfine birakllirsa ya davulcuya vartrd, ya zurnactya!, hoppala kadınlar, yosma karı, uygunsuz avrat, sütsüz, beton gibi kar,, iğrenç kadın, görgüsüz bir çamaşırcı kadın, badem şekeri, lokum lokum, zilli, alçak kadın, kenar mahalle kızları, kız kısmının işine akıl sir ermez, kahpe karı, lekeli bir kız, alnının kara yazısı, el mal, zarına bakma, etekleri havalanmış bir kız, koklandiktan sonra kaldırlip atılacak, azgin kaltak, pis lanet, meymenetsiz karı, kanı biraz aşırı oynak, kahpe, çirkef karı, kayarto" (O, Kemal 2012b: 2, 8, 20, 23, 33, 34, 36, 53, 56, 58, 64, 74, $81,83,98,112,116,127,145,146,179,185,189,191,194)$.

"Sütbeyaz avrad, karı kanck takımı, külhan karl, hovarda karl, güneş görmemiş dilberler, arsız, uzun süre erkeksiz kalmanın azginhğı, el kızı, alt tarafi kancık takımı, kadınların güzellikleri erkekler içindi, antika karl, herkese şapur şupur da, bana yarabbi şükür mü?, kahpe, sürtük, azgın dullar, kütür kütür kadın, azgin bir erkek delisi olan kadın, ne yavru, cıvl cıvıl taze, kabak çiçeği gibi aç̧lmış, melune, beleş bir avrat, facire, azgın bir kısrak, alt tarafi Elçi Cemşir'in amele kızı, orospu, zilli, sürtük, Ermeni gelini gibi, kız kısmı yetişip gelince elbette fingirderdi, doğuran kısrak utansın, beş paralk iş̧̧i kızı, eksik etek, kafes ardı kız, kahpe, yedi denizin dışarı attığı, lanet, soyka, eşek kafah kız, elma kurtları gibi kıvranan kar beyaz kadınlar, erkek kadının küçük tanrısıdır, kâfir 
karı, kaba saba işçi karısı, hımbıl, huylanmış bir kısrak gibi, cadı, kahpe dölü, yırtık bir kız, el kızlart, şehir sürtükleri, hayasız bir kız, gözleri dönmüş kaltak, kocalarını köleleri, ilik ilik avrat, fabrika sürtüğü, iki paralık fabrika kızı, maymun, yadırgı avrat, yazını fabrika amelesi, kartoloz, silik, kancık it kuyruğunu sallamasa, avrat kasığında yatmak, azgın kadın, gudubet, fabrikada çalışan bir kızın güzelliğinden, namusundan ne çıkar?, bacım olacak kahpe, böyle kız düşman başına, utanmaz, arlanmaz, kız eksiği” (O, Kemal 20o9a: 4, 5, 7, 27, 32, 48, 51, 53, 54, 65, 68, 8o, $88,94,95,106,111,118,122,128,142,149,155,157,160,161,184,199,211,241,247,249,250,258$, 259, 263, 291, 292, 293, 295, 297, 314, 315, 321, 337, 345). “Çingene maşası, soyka, fink atan, kancık it, çalmadan oynayan cinsten, çorabı düşük, avrat istemeye görsün, bir tabur asker vız gelir, yeni gelin cilvesi, zambırl, arsız cenabet, bingıl bingıl kız, edepsiz, kahpe dölü, fallikler-sürtükler, pasakh geveze cenabetler, elinin artığı kapatma, kâfir karı, pis orospu, kokmuş karı, kart karı, edepsiz, yazının iki paralık amelesi, kerhane orospusu, kahpe kasığında yatmış, kenarın dilberi, avradı olacak orospu, kadın bu dünyanın en harikulade oyuncă̆ı, ağzı çabuğun biri, yazının aç iti, yezit bir kız, hazdan kurttarak, başkalarını keyfi, zevki için 'vasıta', it nefisli, rezil karl, avrat gemi azıya almış, yazını sürtüğ̈̈̈" (O, Kemal 2009b:4, 5, 6, 7, 8, 17, 40, 47, 54, 58, 6o, 61, 71, 85, 86, 87, $91,126,138,140,163,189,207,219,239,265,266,323,345)$. "Etekleri havalı bir genç kadın, yabani karı, o biçim karl, postal, bir içim su, kitap gibi avrat, Aladağdan serin soyka, beş paralık bir çamaşırcı karı, alt tarafi bir kancık” (O, Kemal 2013b: 4, 34, 35, 37, 103, 116, 192, 213).

"Sacı uzun aklı kısa, sonradan görmüşlerin beslemesi, mızmız karı, etekleri havalı hoppa kızlar, erkeğe doyamayan, sidikli, şişe kafal, at surath kız, burnu havada, doğuran kısrak utansın, vay kahpe analı vay, zilli, boynu ensesinden kesilecek findıkçı" (O, Kemal 2015c: 13, 21, 25, 43, 50, 68, 71, 75, 150, 172, 173, 272). "Hamurlu avrat, kahbe, orospu, avrat dediğin bir esvaph şeytan, herkese şapur şupur da bize yarabbi şükür mü, deli soyka, kancık, postal, fallik, aptal kızı dediğin bir Çingen, azgin orospu, kahpe dölü, yollu, oynak orospu, avrat dediğin de ne? dört parmak sidikli bağırsak, kahpe avrat, kahpe anahlar, karı kancık kısmı lâf anlar mı, kahpe dölleri” (O, Kemal 2014c: 20, 82, 150, 163, 166, 167, 168, 183, 191, 194, 195, 200, 217, 317, 319, 373, 375).

"Siska suratsı, pis, mendebur, maymun, lanet kadın, etekleri haval, kâfir kız, kakavan karı, hoppa kızlar, karı kancık takımı şeytân-ı lâin'in hamurundan hayır çamurundandı, o biçim, ağzı sigaralı kadınlar" (O, Kemal 2007b: 5, 8, 17, 66, 69, 102, 117, 132, 275, 307). "Hizmetçi ruhlu anne, kâfir kız, kocakarı, mendebur karı, densiz karı, şıllık, yazını çıplağı, donsuz şıllık, azgın karı, çorabı düşük, postal, şeytanın alt bacağı, yarım pabuçlu mahalle karısı, erkeğin elinin kınası, yazının seksen erkekle düşüp kalmışı, maymun surat, lekeli kadınlar, şeytana pabucu ters giydirecek cinsten, on parmağında on kara, kadındı nihayet, yollu, yazının peş paralı sürtüğü, püsküllü bela, çorabı düşük, enayi pilakisi, şirret, müsrif, hayasız, zehirden şifa, orospudan vefa" (O, Kemal 2015b: 12, 21, 35, 41, 43, 45, 50, 57, 78, 84, 91, 97, 125, 131, 149, 163, 209, 212, 223, 230, 264, 267, 274, 351). "Hoppa, kötü kadının kocası, kötü kadının kızı, yılan, zararsız deli, kaşkaloz, karını irin sütünü emmek, pis musibet, kancık it kuyruğunu sallamasa, çıfit, zehirden şifa orospudan vefa, kancık, kahpe, kaltak, etekleri havah findıkkurdu, harap bir kocakarı" (O, Kemal 2013a: 10, 14, 19, 36, 57, 63, 82, 168, 173, 179, 304).

"Karı kancık milleti, birbirini it gibi dalayıp şurda küser şurdaysa barışırdı, yazının çıplağı, laf dedin mi çuvalnan avratta, lanet karı, kahpe, fallik, el kızı, uğursuz karı, karı kancık takımında gerçekten de akul yoktu" (O, Kemal 2005: 24, 29, 71, 176, 257, 287, 350). "Boyalı dudaklarm kirli etekleri, elinin hamuruyla erkek işine karısmak, erkek suratl karı, kart karı, kart, buyıkl, kokmuş karı, gözü göz değil kahpenin, sağlam ayakkabı değil o, kancık köpek kuyruğunu sallamasa erkek köpek..., şeytan kadın, kadın! en iyisinin boynu altında kalsın, deli soyka, yazını delisi, kadın nerden baksan zayıf mahluk, tapon" (O, Kemal 2012a: 11, 68, 69, 76, 125, 148, 160, 181, 232, 243, 281). "Postal, kuru bamya, kahpe kasığında yatmış, beş kuruşluk hizmetçi parçası, yazının ne idiği belirsiz kahpesi, elden artakalmıs, el kapılarında çalışanlardan hayır gelmez, ellenip sıkılmamışı her bir şey yapılmamışı olmaz, dilli düdük” (O, Kemal 20o7c: 111, 194, 235, 239, 276, 30o, 334, 369). "Gâvurun kızı, kocakarı" (O, Kemal 201Oa: 23, 165). "Gidinin kancığı, kahpe karı, kıskançhlk yılanı birden başın kaldırır, edepsiz, yüz karası, gâvurun kızı, kısrak kadar cilveli, kaltak” (O, Kemal 2008b: 59, 60, 39, 101, 120, 153, 172).

Orhan Kemal romancı kimliğiyle toplumun içinde var olurken, edebiyatını, her yönüyle gördüğü toplumsal kesimlerin gerçeklerine dayandırmayı başarmıştır. Yaşadığı toplumdaki erkek egemen hiyerarşinin, yalnızca kadının toplum içindeki konumunu tayin etmekle kalmayıp aynı zamanda kullanılan dilin, kadını meta gören aşağılayıcı yönünü de roman içeriğine taşımıştır. Yukarıda erkeklerin kullandıkları mizojinik söylemler bunu doğrular göstergelerdir. Ayrıca toplumsal yapısıyla değişmekte olan bir Türkiye'nin, daha çok refah içinde yaşayamayan toplum kesimlerine eğilen Orhan Kemal'in 
romanlarındaki kadın karakterler, eşitsizleştirici koşulların olumsuz etkilerini yansıtırlar. Yaşadıkları sosyal sorunların benlik algılarında bir olumsuzlama getirdiği ve sosyal sorunların kişiliklerine sinmesi bir yana, bu süreç içerisinde erkeklere göre daha kötü koşullara hapsedildiklerini söylemek mümkündür.

\section{Kemal Tahir'in romanlarında kullanılan mizojinik söylemler}

Kemal Tahir, Türk edebiyatında toplumcu kuşak içerisinde kendisine özgü roman anlayışıla yer edinmiş ve ileri sürdüğü tezlerle Türkiye düşünce yaşamına ilişkin birçok tartışmanın içinde her dönem önemini korumuştur. Kemal Tahir, "çağımız Türk romanında işini en ciddiye alan, neyi, neden, nasıl, yaptığım ve yapacağın bilmekle birlikte bütün bunları en çok araştırıp incelemek için büyük bir çaba sarf etmiştir. Her romanın nasıl yazdiğı, ayrı bir roman konusu olacak denli çileli bir çalışmadır" (Nesin 2017: 199). Anadolu kırsal yapısında geçen romanlarında, köy insanının sosyal karakterini tüm yönleriyle verirken; sosyal ve tarihsel olaylar karşısında insanların tutumlarını, onların sosyal psikolojilerini de anlamamızı sağlar. Dahası Tahir’in tarihsel içeriği ağır basan romanlarında Türk insanının kültürel ve sosyal yapısını çeşitli olanaklarıyla birlikte analiz edebilmekteyiz. Bütün bunların yanında unutmayalım ki, Kemal Tahir’in roman örgüsünün çerçevesini ataerkil değerler üzerine inşa edilmiş bir toplumsal yapı var kılar. Bu örgü içinde kadın bir fail olmaktan öte adeta bir yan figürdür. Erkek dünyasının katı hiyerarşik koşulları karşısında, kadının statüsü çok aşağılardadır. Özellikle yoksullukla ilişkili bir sonuç olarak, kadın eğitimsiz olmanın yanında çoğu zaman cinsiyet rollerine dayalı bir yana sahipken, ataerkil sosyalleştirme sürecinden geçen erkek içinse çoğunlukla bir meta ve cinsel bir obje gibi görülür. Tahir’in romanlarını mizojinik söylemler açısından ele alırken, aşağıda bu açıdan kullanılan söylemler ve kadını aşağılayan önyargı yüklü sözcüklerle ilgili bir değerlendirmede bulunduk.

"Ev piliçleri, erkek yamyamı, erkeğin bir nefsi olur karının on nefsi, karı milletinin yılgını çekilmez, herifini sınamayan karı hovarda kullanmaz" (Tahir 2015a: 11, 33, 141, 156, 164). "Sıkı işe gelmez kötü karı, Yunan'dan peydahlanmış kahpe anaları, gücüm yetse kaçar mıyım karı gibi" (Tahir 2014b: 77, 308, 345). "Kaz boğazı kız boğazı, mahpusun parası pul karısı dul, hey karı milleti! bir şey olsa ağlar" (Tahir 2015c: 86, 111, 376). "Etekli şeytan fendi, karmın oynağı eşek olur, karı milletinin derdi n'olur, ya birine sevdalanmıştır ya da kocası soğuk, kötü karı, yüreği kahpe karı yüreği, orospu, kahpe" (Tahir 2016a: 56, 59, 71, 75, 203, 310). "Avratlar gibi çalkalanarak, Levanten kahpe, kız on para etmez, akıll kadınlar yorucu olur, adam eti yiyen bir kahpe” (Tahir 2014a: 71, 183, 196, 385). "Acemi orospu, kahpe karının neden çocuğu olmaz? biri yapar biri bozar da ondan, yabanın kara kahpesi, kahpe kısmı bildiğimiz kenef, karı milleti kurmızı donlu şeytan, orospu, hayvan yaniya kahpe karı, karı milletinde akıl ne arasın, karı yollu, kocasın denemiyen karı orospuluk edemez, kahpe karı doymazhğı, karı oynak ve azgın, namusuz, karı işi kancık işi, karı milleti şeytan, kahpelik Allah vergisi, kötü orospu, kahpe kısmını kanın hükümet aramaz, orospunun yiğidi olmaz" (Tahir 1958:14, 43, 117, 134, 146, 217, 236, 252, 261, 263, 287, 295, 302, 314, 315, 319, 320, 312, 343).

"Kocamayı karılar düşünsün, kahpe karı, bu sarı altınla cilveli karıya dayanan memur olmaz, dilini tutamadığından baltayı ayağına vuran karı milleti, yakıcı kahpe, karı milletinin akh mı erer, karı milletinin yola gelmeyeni olmaz, karı milletinin oynağı bir zararsa durağanı beş zarardır, kudurgan kahpe, kahpe kısmını paraya dayananı hiç olmaz, yangına düşmüş oynak karı dalgınlı̆̆ , karı kısmı şeytanlı fistan, karı kısmı tavuk gibidir ardı güdülmez, ersiz karı milletine yarar iş değil, karı düşmandan korkmah, karı kısmmın olura olmaza he demesi yularsızlı̆̆ındandır, karının şeytanı karı, cinli kahpe, ersiz avrat şeytanla çiftleşir" (Tahir 1990: 12, 28, 101, 169, 174, 177, 203, 212, 232, 297, 302, 304, 339, 370, 373, 377, 403). "Kahpe, kart kısmı tüm rezil, tavuğu buğday tanesiyle çekip getirirsin karıy üzüm tanesiyle, kız milleti avanak olur, kolay aldanır, orospu, ulan kahpe, düşte karı görmek esvapl şeytana uğramaktır, karı kısmında bir tutam akıl yok, karı milleti rezildir, kız gibi ahmak, kız kısmı karnımı doyuracă̆ yerin mall, tabancaya, kariya bir de saate kefil olunmaz" (Tahir 2016c: 1, 2, 24, 42, 54, 67, 82, 87, 100, 125, 150, 277). "Rezil kahpe, karı kısminın aklı var da fikri yok, dul karı metelik etmez, orospu, kaşık düşmanı, oğlanı görünce suratı kızaran malı hemen evermeli, cadı karı, kahpe eskisi, karı şeytanın kendisi, karı milletine güvenilmez, orospu karmın girdiği yerde bereket olmazmış, kocasını 
denemeyen karı orospuluk edemez, kötü karı adam sevmezmiş, kendi mah olmayınca adam karıya acımaz, harama alş̧an karı duramaz, karı milleti laftan korkar da günahtan korkmaz, karı milletinin dini imanı yoktur, karı kısmı erkek işine karışmaz" (Tahir 2013a: 10, 15, 60, 69, 94, 136, 209, 255, 271, 282, 294, 348, 399, 412, 415, 418, 441). "Karı gibi sırıtma, karı kısmının saçı uzun, aklı kısa olur, kullanılmış mal, karı milleti vara yoğa ağlar” (Tahir 20o8: 35, 39, 105, 270).

"Kahpe, orospu” (Tahir 2014c: 79). "Kahpe avrad, kız milleti bütün avanak, silah kapturacağın yerde karıı ver, akıl olsa kız olmaz, eksik etek, karıdır akl kısa, orospu, karı kısmı eksik etek, fazladan sacı uzun, kahpe karı töbe tutar mi" (Tahir 2015b: 46, 140, 153, 213, 229, 230, 331, 374). "Karı dediğin el kiridir, yıkarsın geçer, yıllanmıs kart kahpe, saçı uzun akh kısadır, hayvan gibi fikri yoktur, kancık it, karı kısmı şeytanın kendisi, aşifteliğin sonu kurşun, karı kısmı zaten körpeliğinde azar, karıyı hovarda akıllandırır, karının kanı bir kuruş namus yüz kuruş, esvaph şeytan" (Tahir 2013b: 16, 30, 41, 59, 138, 228, 273, 274, 275, 282). "Kötü kart, karı kısmı sopasız olmaz, karı milletinin ya saçı kurumayacak ya da gözü, dünya güzeli de olsa karı milletinin hepsi eşek, karı milletinin oyununa hiç akıl ermez ve de karı kısmına güç yetmez, karı milletinin birinci şeytanı paradır, karı kurnaz bir orospu" (Tahir 2010: 19, 32, 69, 155, 277, 296). "Her karmm adı birdir karanlkta tadı birdir, gavur, hayvan gibi bir karı, edepsiz orospu, orospu öldürmek temizliktir, karı milleti zaten rezil, kız kısmı şeytan olur, esvapl şeytan, yabanın kahpesi” (Tahir 2016b: 8, 38, 45, 62, 90, 119, 120, 201, 278). "Kart kahpe" (Tahir 2013c: 369).

"Erkeğin şeytanı karı, kahpe, anadan oynak erkek canlısı, hasta karını dermanı er, karı milleti tavuk gibidir ardı güdülmez, karı karmın șeytan, karı milletine inan olmaz, karı milletinde akıl yok" (Tahir 1976: 58, 63, 66, 184, 270, 421, 422). "Bu kadın milleti can sıkıcı bir şey, ağlama karı gibi, eksiketek, orospuları sevmek olmaz, kız kısmın insan oyuncak niyetine seviyor, sokak süpürgesi, kız kısmı bir defacık kız olarak kullanılır sonrası hep duldur, kadınla şaka edersen zina olur, kadın denilen korkunç mahluklar" (Tahir 1995a: 51, 69, 84, 106, 132, 295, 319, 328, 350). "Kız kara şeytan, bütün güzel kadınlar ahmak olurlar, âşifte” (Tahir 1995b: 394, 443, 541). “Aptal kız, budala karı, erkek kısmı kırk senede bir kere karı sözü dinleyecek, uygunsuz takımından bir kadın, bir kadının eteğine dolmak, kaltak, erkeksizliğe bindebir karı dayanamaz, güzel kadınlar ekseriya ahmak olurlar, kızını dövmeyen dizini döver, kadın kısmına inanılır mı, Çingene maşası" (Tahir 1995c: 43, 51, 53, 70, 103, 200, 297, 343, 376, 425, 490).

Genel hatlarıyla değerlendirdiğimizde, Kemal Tahir’in yukarıda romanlarından örneklediğimiz kadınları aşağılayan söylemlerin ve erkeklerin dünyasında üretilen, kadını dışlayıcı cinsiyetçi kavramların, günlük dil içinde de yer ettiğini görürüz. Kadın adeta ötekileştirilmiş, kamusal/mahrem alanda cinsiyetine ilişkin olumsuz yargılar konuşma kalıplarına sinmiş ve normalleştirilmiştir. Toplumun bir değeri olan roman yazarlarının, yaşadıkları toplumun çelişkilerini ve özelliklerini işledikleri düşünüldüğünde, Tahir’in kadınlara yönelik değersizleştirici söylemleri verirken, aslında toplumun bu anlamda egemen dilini romana beceriyle yansıttığını söyleyebiliriz.

\section{Yaşar Kemal'in romanlarında kullanılan mizojinik söylemler}

Toplumsal cinsiyet açısından kadınlara yönelik sözel şiddet ile özdeşleştireceğimiz mizojinik söylemlere Yaşar Kemal'in romanlarında da rastlamaktayız. Orhan Kemal ve Kemal Tahir'de olduğu gibi Türkiye gerçeklerini romanlarına aktaran Yaşar Kemal'in, bu toplumsal gerçekliğin kadına dayattığı toplumsal cinsiyet normlarını roman olay örgülerindeki insan ilişkilerine taşımaması beklenemez. Toplum içinde kadına yönelik aşağılayıcı söylemler, patriyarkaya dayalı toplumun her aşamasında kendisini çeşitli şekillerde hissettirir. Aşağıda yazarın romanlarından yola çıkarak bunu doğrulayacak alıntılara yer vereceğiz.

“Orospu gelin, koca kaltak, kaltak, orospu avrath, pasakh gelin, orospu gelinli, koca orospu, nankör analar, kadın kısmı da bir korkak olur ki, boynuzlu herifin avradı, kız çocuğu el kiri yıkarsın gider" (Y, Kemal 200oe: 12, 15, 25, 47, 57, 60, 64, 104, 131, 261). "Kancığılan çıkma yola başına getirir bela, erkek olmayanın yalanı çoktur, eksik eteklerde hiç akıl yoktur, orospuda iman olmaz din olmaz, fallik, ağzı kanlı kancıklar, orospu avradı, saçları kökünden kesilesiceler, avratların donunu almak, eksik etek, avrat yürekliler, karlar gibi beddua etmek, kanclk, pis kız" (Y, Kemal 20oof: 9, 10, 37, 40, 64, 79, 162, 193, 218, 220, 354). "Yedi düvel orospusu, avrattan kötü, eksik eteklerde iman olmaz, 
din olmaz, orospu gelin, azgın kadınla başa çıkılmaz, hayasız karı, domuz karı, mendebur bela karı" (Y, Kemal 2ooog: 15, 19, 39, 43, 58, 62, 124, 232).

"Anasını atın tepelediği, orospu analı, karı gibidir bre!, kızı kendi gönlüne bıraksan ya çingeneye vartr ya da davulcuya, avrat yürekli adamlar, orospu, orospu dölü, gavurun kızlart, avratlarm yaşhlı̆̆ı da cip beter oluyor, orospu çocuğu, pasaklı karı” (Y, Kemal 20ooa: 41, 66, 88, 111, 137, 221, 242, 248, 266, 383). "Koca karl, mendebur karl, kaltak" (Y, Kemal 20oob: 25, 26, 115). "Yalancinun o güzel avradın cümle alem düdüklesin mi?, ahmak avrat, fallik, orospu avrath, avrat yürekli, avrat milleti değil mi, korkak ahmak orospu" (Y, Kemal 20ooc: 4O, 156, 157, 162, 389, 476, 479). "İsterik orospu, köylü orospuları, kız fallik, karısının eteği altına saklanmak, yaşh kaltak, ihtiyar orospu, orospular sultani" (Y, Kemal 20ood: 81, 404, 419, 436, 484, 485).

"Yatakta osura osura avratlar ölür, tosun gibi kadın, naml orospu, avrat yapıl herifler, orospu kasığında yatmış, orospu avratlar" (Y, Kemal 1998a: 106, 170, 171, 181, 343, 403). "Allahın belası bir kız, karılar gibi ağlamayı bırak, kadın gibi korkak, bu devirde kızın kırıştıranı makbuldür, karıları orospu, avrattan kötü, cam gözlü kaltak, bütün kadınlardan daha orospu, Arap kısrağına benziyor, orospu dölü, eteğine hiç dayanmaz" (Y, Kemal 1999a: 119, 219, 26o, 288, 292, 306, 374, 401, 444, 475). "Dedikoducu bir kocakar" (Y, Kemal 1998b: 411). "Kadın kini deve kini, köyün orospusu, bilmem kızgın neresini soğutmak için, ananınkine kına yak" (Y, Kemal 1999b: 18, 95, 361, 446). "Orospu çocuğu, cad,, Zero için Osmanl bir eksik etektir” (Y, Kemal 1999c: 149, 363). "Cenabet karı" (Y, Kemal 20o2a: 482). "Orospular” (Y, Kemal 20o2b: 315). "Gönülsüz kız çürük iş" (Y, Kemal 2001a: 48). "Kızlar erkeklerin başına beladır” (Y, Kemal 2OOoğ: 50). "Orospu kasığında yatmış, orospu anadan da böyle deyyus doğar, kocamış cadı” (Y, Kemal, 2001b: 34, 41, 90).

“Orospu dölü” (Y, Kemal, 20ooh: 68). "Sümüklü sürtükler, karı milleti de bela, şarmuta, yelloz, fallik” (Y, Kemal 2013: 27, 55, 62). "Orospu kucağında yatmış, kahpenin doğurduğu” (Y, Kemal 200oı: 49, 119). "Avrattan kötüler, gönülsüz karl acı zehire benzer, avrat yürekliler” (Y, Kemal, 2001c: 177, 180, 186). “Orospu analı, orospu kasiğında yatmış, orospu oğlu” (Y, Kemal 1998c: 9 , 132). "Kazın biri, Allahın sümüklü maymunu, kocakarı, cadaloz, yabanın orospuları, mahallenin baş orospusu, orospu çocuğu, zamazingo" (Y, Kemal 2oooi: 24, 94, 95, 117, 201, 298, 314).

Kadınları olumsuzlamak için kullanılan yukarıdaki nitelendirmelerden hareket edilerek denebilir ki, kadının ataerkil toplumdaki yeri, erkek egemen ideoloji tarafından toplumsal yaşamın her alanında belirlenmiştir. Çünkü egemen olan eril dilde de aşağılanan hep kadındır. Ekonomik ve siyasal yapının erkeklerce kodlandığ bir sosyal iklimde kadın biyolojik işleviyle ve kadınlık rolleriyle sınırlı bir dünya içinde ele alınır. Erkeklerin egemen olduğu toplumlarda ortaya çıkan sonuç, söylem düzeyinde dil açısından inciticidir. Bu dil, toplumsal yapının sosyal analizinde toplumsal cinsiyet ayrımcllğının izlerini taşıdığı için sosyolojik değerlendirmelerde önemsenmelidir. Yaşar Kemal gerçekçi bir romancı kimliğiyle bu cinsiyetçi dili romanlarında yansıtırken eleştirel bir okuma alanı açmıştır. Kısaca sosyal bir olgu olarak ve toplumsal yapıyı çeşitli boyutlarda işleme ve aktarma yönleriyle edebiyat/roman baştan sona tarihseldir, aşamaları, doğuş yerleri, gelenekleri, mirasları vardır. Bu bağlamda romanın sosyal-tarihsel yönü ağır basar. Buna dayalı işlenen romanlarda ise mizojinik söylemlerin varlığı romanın geçtiği toplum hakkında sosyolojik bilgi sunar. Çünkü her şeyden önce roman kişilerinin yanı sıra romandaki yaşantının da kantara vurulduğu yer, dış dünyanın gerçekliğidir (Derrida 2006: 177, Türkeş 2009: 844).

\section{Sonuç ve değerlendirme}

Orhan Kemal'in romanlarında hem erkeklerin hem de kadınların kullandığı, toplumsal cinsiyet açısından kadınları aşağılayan, ötekileştirici bir dilin kelimeleri yer almaktadır. Yazarın üst anlatıcı olarak kendi kullanımı değil de, romanlarındaki karakterlerin diyaloglarında kadını aşağılayan söylemlerin geçiyor olmasını, aslında kadınlara bakış anlamında yaşananları toplumsal yapının görünümüne ilişkin olarak değerlendirmek gerekir. Diğer yandan Yaşar Kemal'in romanlarında, çok az olmakla birlikte, toplumsal cinsiyet normlarının nasıl yeniden üretildiğine; bunun ne tür çağrışımlara neden olduğuna, toplumu yansıtmayı başardığı için örtük olsa dahi kısmen tanık oluyoruz. Bu açıdan Yaşar Kemal’in kadın olgusuyla ilgili farkındalığını teslim etmek gerekir. Yani en olumsuz toplumsal 
koşullarda bile kadının bir saygınlığı vardır. Kemal Tahir’in roman dünyası ise verili ataerkil toplumsal yapının büyük ölçüde yeniden üretimi olduğu için erkek dünyasında mahkûm edilen kadınların ötekileştirilmesi daha bir ön plandadır. Kısaca ataerkil hiyerarşinin biçimlendirdiği toplumda, yoksulluk ve eğitimsizliğin, kadının sosyal statüsünü düşürdüğünü, kadınların kendi cinslerine bakışında bile erkek zihniyetini dışa taşıdıklarını görürüz. Kadın, erkeğin adeta mülkiyeti gibi görülür. Güç tutkusunun ve elde edemediğinde nefretinin nesnesi olabilmektedirler. Bu, söylemlerin özünde yer almaktadır.

Aslında temel mesele Türkiye'de siyasal rejimin ve toplumda egemen değerlerin otoriterliğinin arkasındaki ataerkil desteklerin, değerlerin ve kurumsal pratiklerin cinsiyet rejimi analizinin sunduğu farklı mercekler ve bakış açılarından da sorgulanabilir hale getirilebilmesidir (Sancar, 2015: 18). Roman açısından bu yapıların analizi, sosyal yaşam pratiklerini anlamak adına önemlidir. Her üç yazar açıkçası feminist eleştirinin konuları arasında yer alacak şekilde, ataerkil düzende dilin de kadını aşağılama ve ezme aracı olduğunu belirterek, kendi toplumcu dünya görüşlerine uygun davranmışlardır (Moran, 1999: 262). Ayrıca bu yazarlar, romanlarının yazıldığı koşullarda toplumun sosyolojik arka planını işlerlerken, erkek egemen sosyal sistemlerdeki toplumsal eşitsizliklerden kaynaklı cinsiyet hiyerarşisinin, kadınlar aleyhine kurgu bulmuş ataerkil bir dile ilişkin patolojik yanı da resmetmişlerdir. Her üç yazarın romanlarından bu yönüyle sınırlayarak dökümünü yaptığımız mizojinik kelimeler, hiç kuşkusuz bu yazarların, bir romantizme kapılmadan yaşadıkları toplumun gerçeklerini işlemelerini sağlayan toplumcu bir düşünceye sahip olmalarıyla bir bütünlük gösterir. Biliyoruz ki sosyolojik bir olgu olarak kabul ettiğimiz romanda kullanılan dil de toplumsal gerçekliği taşır...

Son tahlilde Orhan Kemal, Kemal Tahir ve Yaşar Kemal'in roman arkeolojilerinde kadın karakterler, erkek egemen dünyanın incitici söylemlerini yaşamaktadırlar. Bu nedenle tarihsel dönemler içinde yazdıkları romanlarıyla, toplumsal yapıda sözel/psikolojik şiddet gören kadını çözümlememiz için birçok veriyi sunmuşlardır. Aynı zamanda okurun, yazarların anlatı stratejilerine müdahil olabilmesi, eleştirel yaklaşabilmesi, hatta okur/kadın, olayları ben yazıyorum dese nasıl kurgular, tartışmaları için ise kapı aralamışlardır.

\section{Kaynakça}

Alver, K. (2018). “Edebiyat, sosyolojiye ne anlatabilir”. M. Ali Akyurt (Ed.). Edebiyat ve sosyoloji (s.1335). İstanbul: Alfa.

Bahrani, Z. (2018). Babil'in kadınlar mezopotamya'da toplumsal cinsiyet ve temsil. S. Çalcı (Çev.). İstanbul: Kolektif Kitap.

Collin, F, Kaufer, I. (2016). Feminist güzergâh. G. Acar Savran (Çev.). Ankara: Dipnot.

Derrida, J. (2006). Gün doğmadan, elisabeth roudinesco ile konuşma. K. Sarıalioğlu (Çev.). İstanbul: Dharma.

Ergüven, R. A. (1988). Sanat ve erotizim. Ankara: Yaba.

Fischer, E. (1993). Sanatın gerekliliği. C. Çapan (Çev.). (7.Baskı). Ankara: Verso.

Kemal, O. (1995). Müfettişler müfettişi 1, (7. Baskı). İstanbul: Tekin.

Kemal, O. (2004). Cemile. (12.Baskı). İstanbul: Epsilon.

Kemal, O. (2005). Eskici dükkânı. (11.Baskı). İstanbul: Epsilon.

Kemal, O. (2007a). Sokaklarnn çocuğu suçlu 2. (9. Baskı). İstanbul: Everest.

Kemal, O. (2007b). Yalancı dünya. (10.Baskı). İstanbul: Everest.

Kemal, O. (2007c). Gurbet kuşları. (7.Baskı). İstanbul: Everest.

Kemal, O. (2008a). Suçlu 1. (13. Baskı). İstanbul: Everest. 
Kemal, O. (2008b). Oyuncu kadın/Gâvurun kızı. (6.Baskı). İstanbul: Everest.

Kemal, O. (2009a). Vukuat var hanımın çiftliği 1. (12.Baskı). İstanbul: Everest.

Kemal, O. (2009b). Hanımın çiftliği 2. (14.Baskı). İstanbul: Everest.

Kemal, O. (2010a). Dünya evi. (9.Baskı). İstanbul: Everest.

Kemal, O. (2010b). Üçkâğıtçı müfettişler müfettişi 2. (11.Baskı). İstanbul: Everest.

Kemal, O. (2012a). Kanlı topraklar. (10.Baskı). İstanbul: Everest.

Kemal, O. (2012b). Kötü yol. (10. Baskı).İstanbul: Everest.

Kemal, O. (2012c). Evlerden biri. (13. Baskı). İstanbul: Everest.

Kemal, O. (2013a). Sokaklardan bir kız. (13.Baskı). İstanbul: Everest.

Kemal, O. (2013b). Kaçak hanımın çiftliği 3. (16.Baskı). İstanbul: Everest.

Kemal, O. (2014a). Arkadaş ıslkkları. (10.Baskı). İstanbul: Everest.

Kemal, O. (2014b). Devlet kuşu. (10. Baskı). İstanbul: Everest.

Kemal O. (2014c). Bereketli topraklar üzerinde. M. Vesek (Hzr.). İstanbul: Everest.

Kemal, O. (2014d). Tersine dünya. (5.Baskı). İstanbul: Everest.

Kemal, O. (2015a). Bir filiz vardı. (11. Baskı). İstanbul: Everest.

Kemal, O. (2015b). El kzzı. (20.Baskı). İstanbul: Everest.

Kemal, O. (2015c). Murtaza. (23. Baskı). İstanbul: Everest.

Kemal, O. (2015d). Kenarm dilberi. İstanbul: Everest.

Kemal, Y. (1998a). Demirciler çarşısı cinayeti/Akçasazın ağaları 1. (3.Baskı). İstanbul: Adam.

Kemal, Y. (1998b). Yağmurcuk kuşu kimsecik 1. (3.Baskı). İstanbul: Adam.

Kemal, Y. (1998c). Deniz küstü. (3. Baskı). İstanbul: Adam.

Kemal, Y. (1999a). Yusufçuk yusuf/Akçasazın ağaları 2. (3.Baskı). İstanbul: Adam.

Kemal, Y. (1999b). Kale kapısı/Kimsecik 2. (3. Baskı). İstanbul: Adam.

Kemal, Y. (1999c). Kantn sesi/Kimsecik 3. (3. Baskı). İstanbul: Adam.

Kemal, Y. (2000a). İnce Memed 1. (8.Baskı). İstanbul: Adam.

Kemal, Y. (200ob). İnce Memed 2. (6. Baskı). İstanbul: Adam.

Kemal, Y. (2000c). İnce Memed 3. (6. Baskı). İstanbul: Adam.

Kemal, Y. (2000d). İnce Memed 4. (6.Baskı). İstanbul: Adam.

Kemal, Y. (2000e). Ortadirek/Dağın öte yüzü 1. (5.Baskı). İstanbul: Adam.

Kemal, Y. (200of). Yer demir gök bakır/Dağın öte yüzü 2. (7. Baskı). İstanbul: Adam.

Kemal, Y. (200og). Ölmez otu/Dağın öte yüzü 3. (5. Baskı). İstanbul: Adam.

Kemal, Y. (200oğ). Kuşlar da gitti. (5. Baskı). İstanbul: Adam.

Kemal, Y. (200oh). Teneke. (6. Baskı). İstanbul: Adam.

Kemal, Y. (20001). Çaktrcalı efe. (5. Baskı). İstanbul: Adam.

Kemal, Y. (200oi) Al gözüm seyreyle salih. (4. Baskı). İstanbul: Adam.

Kemal, Y. (2001a). Binboğalar efsanesi. (5.Baskı). İstanbul: Adam.

Kemal, Y. (2001b). Yılanı öldürseler. (8. Baskı). İstanbul: Adam. 
Kemal, Y. (2001c). Üç anadolu efsanesi/Köroğlunun meydana çıkışı, Karacaoğlan, Alageyik. (8.Baskı). İstanbul: Adam.

Kemal, Y. (2002a). Kartncanın su içtiği/Bir ada hikayesi 2. İstanbul: Adam.

Kemal, Y. (2002b). Tanyeri horozlar/Bir ada hikayesi 3. İstanbul: Adam.

Kemal, Y. (2013). Tek kanath kuş. İstanbul: YKY.

Moran, B. (1999). Edebiyat kuramları ve eleştiri. İstanbul: İletişim.

Nesin, A. (2017). Birlikte yaşadıklartm birlikte öldüklerim. (11.Baskı). İstanbul: Nesin.

Sancar, S. (2015). Türk modernleşmesinin cinsiyeti. (3.Baskı). İstanbul: İletişim.

Stendhal, (1999). Parma manastırı. N. Altınova (Çev.). (2.Baskı). İstanbul: Oda.

Tahir, K. (1958). Yedi çmar yaylast. İstanbul: Düşün.

Tahir, K. (1976). Bozkrrdaki çekirdek. (3.Baskı). Ankara: Bilgi.

Tahir, K. (1990). Büyük mal. İstanbul: Adam.

Tahir, K. (1995a). Hür şehrin insanları, I. (3.Baskı). İstanbul: Tekin.

Tahir, K. (1995b). Hür şehrin insanları, II. (3.Baskı). İstanbul: Tekin.

Tahir K. (1995c). Bir mülkiyet kalesi. (3.Baskı). İstanbul: Tekin.

Tahir, K. (2008). Kelleci memet. (8.Baskı). İstanbul: İthaki.

Tahir, K. (2010). Köyün kamburu. (3.Baskı). İstanbul: İthaki.

Tahir, K. (2013a). Körduman. (2.Baskı). İstanbul: İthaki.

Tahir, K. (2013b). Namuscular. (3.Baskı). İstanbul: İthaki.

Tahir, K. (2013c). Damağası. (3.Baskı). İstanbul: İthaki.

Tahir, K. (2014a). Yol ayırımı/Esir şehir üçlemesi 3. Kitap. (6.Baskı). İstanbul: İthaki.

Tahir, K. (2014b). Yorgun savaşçı. (8.Baskı). İstanbul: İthaki.

Tahir, K. (2014c). Devlet ana. (12.Baskı). İstanbul: İthaki.

Tahir, K. (2015a). Kurt kanunu. (7.Baskı). İstanbul: İthaki.

Tahir, K. (2015b). Rahmet yolları kesti. (6.Baskı). İstanbul: İthaki.

Tahir, K. (2015c). Esir şehrin insanlar//Esir şehir üçlemesi 1. Kitap. İstanbul: İthaki.

Tahir, K. (2016a). Esir şehrin mahpusu/Esir şehir üçlemesi 2. Kitap. (9.Baskı). İstanbul: İthaki.

Tahir, K. (2016b). Karılar koğuşu. (6.Baskı). İstanbul: İthaki.

Tahir, K. (2016c). Sağırdere. (5. Baskı). İstanbul: İthaki.

Türker, Y. (1997). “Şiddetle Seviyorum!” Şiddet, Cogito Düşünce Dergisi, Sayı 6-7, s. 319-322. 1997.

Türkeş, Ö. (2009). "Toplum ve kimlik kurma kllavuzu olarak roman”. T. Bora, M. Gültekingil (Ed.). Modern Türkiye’de siyasi düşünce, dönemler ve zihniyetler (s.844-869). İstanbul: İletişim. 